\begin{tabular}{|c|} 
Jurnal Keolahragaan \\
Volume 4 - Nomor 1, April 2016, (34 - 46) \\
Tersedia online: http://journal.uny.ac.id/index.php/jolahraga
\end{tabular}

\title{
PENGEMBANGAN MODEL BERMAIN SEPAKBOLA UNTUK MENINGKATKAN ASPEK PSIKOLOGIS ANAK USIA 12 -13 TAHUN DI YOGYAKARTA
}

\author{
Muna Aprilianto $^{1}{ }^{*}$, Tomoliyus ${ }^{2}$ \\ ${ }^{12}$ Program Studi Ilmu Keolahragaan, Program Pascasarjana, Universitas Negeri Yogyakarta. \\ Jalan Colombo No 1, Karangmalang Yogyakarta 55281, Indonesia. \\ * Korespondensi Penulis: Email: muna_aprilianto@yahoo.com
}

\begin{abstract}
Abstrak
Penelitian ini bertujuan untuk menghasilkan model permainan sepakbola untuk meningkatkan aspek psikologis (semangat, gembira, dan disiplin) anak usia 12-13 tahun di Yogyakarta. Penelitian ini merupakan penelitian dan pengembangan yang terdiri atas dua tahapan yaitu tahap penelitian pendahuluan terdiri atas kajian literatur, kajian penelitian relevan, studi lapangan dan tahap pengembangan. Sampel Penelitian ini sekolah sepakbola di Yogyakarta. Teknik sampling yang digunakan adalah purposive sampling. Pada uji coba skala kecil dilakukan di Sekolah Sepakbola (SSB) Real Madrid melibatkan 10 siswa dan satu orang pelatih. Pada uji coba skala besar dilakukan di dua tempat yaitu di SSB Real Madrid dan SSB Bina Putra Jaya Sleman dengan melibatkan 38 siswa dan dua pelatih. Hasil validasi menunjukkan model bermain sepakbola anak usia 12-13 tahun layak untuk diujicobakan. Berdasarkan Hasil pelaksanaan pada uji coba skala kecil dan besar secara substansi isi dan pelaksanaan tergolong sangat baik. Hasil penilaian efektivitas model tehadap psikologis anak berupa semangat, gembira, dan disiplin mengalami peningkatan: nilai pertemuan kedua lebih tinggi dari pertemuan pertama. Dapat disimpulkan model bermain sepakbola anak usia 12-13 tahun efektif untuk meningkatkan aspek psikologis berupa semangat, gembira, dan disiplin siswa dalam melakukan latihan sepakbola.
\end{abstract}

Kata Kunci: model, bermain, psikologis, sekolah sepakbola

\section{DEVELOPMENT A PLAYING SOCCER MODEL TO IMPROVE THE PSYCHOLOGICAL ASPECTS OF 12-13 YEARS OLD CHILDREN IN YOGYAKARTA}

\begin{abstract}
This research aims to develop a playing soccer model to improve the psychological aspects (spirit, joy, and discipline) of 12-13 years old children in Yogyakarta. This study is a research and development which consists of two stages. The Preliminary research stage and development stage. The Preliminary research stage consisted of a literature review, relevant research studies and field studies. The Validation involve three people experts. The sampel of take it from soccer school in Yogyakarta. The small-scale tryout was conducted on 10 students and one coach of Real Madrid Soccer School in Yogyakarta. The large-scale trials were conducted with two soccer school on 38 students and two coach of Yogyakarta Real Madrid Soccer School and Sleman Bina Putra Jaya Soccer School. The resul is a playing soccer model for children aged 12-13 years with the title "Playing Soccer in Practice to Improve Psychological Aspects". Based on the small-scale tryout and the small-scale tryout content implementation aspects are in an excellent category. The Psychological development of students assessment resulting in the form of passion, joy, and discipline in playing soccer show improvement: score of the second meeting is greater than the average score of the first meeting, thus it can be concluded thaat the playing soccer model for children age 12-13 years is effective to improve students' psychological aspects, including the aspects of spirit, joy, and discipline in doing soccer practice.
\end{abstract}

Keywords: models, play, psychological, soccer school

How to Cite Item: Aprilianto, M., \& Tomoliyus, T. (2016). Pengembangan model bermain sepakbola untuk meningkatkan aspek psikologis anak usia 12 -13 tahun di Yogyakarta. Jurnal Keolahragaan, 4(1), 34-46. Retrieved fromhttp://journal.uny.ac.id/index.php/jolahraga/article/view/8138

Permalink/DOI: http://dx.doi.org/10.21831/jk.v4i1.8138 


\section{PENDAHULUAN}

Sepakbola merupakan olahraga yang paling bergengsi di dunia bahkan di Indonesia memiliki banyak penggemar yang sangat fanatik. Sepakbola menjadi menarik perhatian karena menghasilkan sebuah drama, gengsi dan seni yang bercampur menjadi satu ketika dua tim bermain dan beradu di lapangan. Sepakbola bukan hanya sekedar olahraga biasa, karena perkembangan sepakbola kian tahun makin berubah, yang dulunya hanya sebagai olahraga untuk menjaga ketahanan tubuh secara fisik dan stamina, sekarang menjadi sebuah pertunjukkan yang menghibur masyarakat umum.

Olahraga harus dilakukan dengan benar, terprogram dengan baik, dan menyenangkan, inilah konsep yang harus diterapkan dalam berolahraga. Dibutuhkan kerja sama yang baik antara pelatih, olahragawan, dan orangtua yang merupakan hubungan timbal balik agar tujuan latihan dapat tercapai (Sukadiyanto, 2010, p. 7).

Tercapainya tujuan dalam olahraga atau prestasi merupakan akumulasi dari kualitas fisik, teknik, taktik, dan kematangan psikologiss olahragawan yang disiapkan secara sistematis melalui proses pembinaan yang benar. Pendekatan yang digunakan untuk memotivasi olahragawan yaitu dengan menekankan pada bentuk dan pola latihan, serta metode latihan yang digunakan. Keberhasilan pencapaian prestasi olahraga juga ditentukan oleh berbagai faktor, salah satunya adalah penjenjangan latihan sesuai dengan tingkat usia anak (Lumintuarso, 2013, p. 15).

Dalam melaksanakan pembinaan sepakbola anak, bentuk latihan harus mengandung unsur bermain di dalamnya. Sebab usia anak merupakan usia bermain sehingga bentuk aktivitas berlatih sepakbola yang diberikan merupakan aktivitas bermain. Dengan pembinaan yang melibatkan unsur bermain akan dapat memunculkan sebuah perasaan yang dapat memotivasi anak dalam berlatih.

Secara umum usia anak menyukai bermain bola, namun kemampuan dasar yang dimiliki setiap anak tidak sama. Kemampuan dasar adalah kecakapan atau bakat yang dimiliki seseorang sejak lahir yang dapat diasah dan dikembangkan sejalan dengan pertumbuhannya. pelatih hendaknya merancang model latihan sepakbola yang melibatkan unsur fisik dan juga bermain. Menyuruh anak untuk melakuklan kegiatan fisik saja dalam waktu yang lama, dirasakan anak sebagai siksaan.
Pembinaan anak merupakan masa penting untuk mempersiapkan kemampuan dasar anak sebelum memasuki tahap spesialisasi yang masih kurang diperhatikan. Padahal anak merupakan modal utama dan sekaligus subjek pembinaan yang menjadi cikal bakal pencapaian prestasi olahraga dikemudian hari. Anak memiliki arti yang semakin penting manakala dikaitkan dengan investasi yang tidak ternilai harganya, tidak hanya untuk prestasi olahraga, tetapi juga masa depan kehidupan.

Olahragawan merupakan satu totalitas sistem psikofisik yang kompleks. Karena manusia terdiri atas unsur jiwa dan raga, maka prestasi olahraga merupakan aktualisasi dari akumulasi perpaduan antara hasil latihan, potensi fisik, dan psikis. Faktor tersebut perlu dijalani dalam proses latihan secara seimbang terutama faktor psikis dan fisik. Namun, kenyataan di lapangan para pelatih cenderung lebih banyak melatihkan unsur fisik daripada psikis, sehingga proses latihan belum berjalan seimbang. Hal ini dikarenakan para pelatih sepakbola merasa sulit merancang bentuk kegiatan latihan sepakbola yang mencakup aspek fisik dan psikis yang disesuaikan dengan perkembangan dan pertumbuhan anak usia 1213 tahun. Hal ini menyebabkan siswa sekolah sepakbola kurang semangat, gembira dan disiplin.

Atas dasar tersebut maka diperlukan model latihan sepakbola yang dapat dugunakan dan diterapkan untuk anak usia 12-13 tahun di sekolah sepakbola di Yogyakarta. Model latihan yang mencakup bermain sepakbola dan disesuaikan dengan karakteristik anak usia 1213 tahun. Diharapkan model ini dapat melatih perkembangan fisik, meningkatkan psikologis (semangat, gembira, dan disiplin), dan bermain sepakbola.

Berdasarkan uraian di atas peneliti ingin mengembangkan model bermain sepakbola anak usia 12 - 13 tahun yang dapat melatih fisik dan meningkatkan aspek psikologis siswa sekolah sepakbola di Yogyakarta.

Psikologis sangat berpengaruh besar terhadap hasil yang dilakukan manusia. Menurut Sarwono (2012, p. 50), psikologis merupakan ungkapan perasaan atau emosi manusia saat bersosialisasi, berinteraksi dengan manusia yang lain maupun kelompok yang ditunjukkan dalam bentuk perilaku. Emosi manusia yang ditunjukkan melalui perilaku tidak terjadi secara sporadis (timbul dan hilang begitu saja), tetapi selalu ada kelangsungan antara satu 
perbuatan dengan perbuatan berikutnya. Dengan kata lain perilaku manusia tidak pernah berhenti pada suatu saat. Perbuatan terdahulu merupakan persiapan bagi perbuatan yang kemudian, sedangkan perbuatan yang kemudian merupakan kelanjutan dari perbuatan yang sebelumnya.

Ada dua macam emosi, yaitu emosi positif dan negatif. Emosi positif menurut Muhadjir (2011, p. 45) meliputi perasaan seperti kegembiraan, kegirangan, sangat gembira, rasa tertarik, kebahagiaan, dan rasa cinta. Sebaliknya emosi negatif meliputi perasaan seperti marah, cemas, bosan, rasa takut, iri hati, benci, keadaan yang memalukan, dan kegusaran. Beberapa emosi tersebut akan muncul dalam perasaan olahragawan baik sebelum, selama, maupun sesudah pertandingan. Kemunculan emosi dipengaruhi oleh kesiapan diri, lawan tanding, kondisi lapangan, cuaca, wasit, penonton, dan hasil yang dicapai menang atau kalah.

Pengertian emosi adalah tergugahnya perasaan yang disertai dengan perubahan-perubahan dalam tubuh, seperti otot yang menegang dan detak jantung yang cepat. Reaksi emosional adalah terjadinya perubahan tingkat kegairahan yang dapat menghambat atau memudahkan keinginan seseorang untuk berperilaku atau bertindak. Biasanya reaksi emosional selalu disertai dengan respons fisiologis seperti meningkatnya tekanan darah, detak jantung, dan ketegangan pada kelompok otot tertentu (Sarwono, 2012, p. 123).

Dalam kegiatan olahraga hubungan aspek psikologis dan aspek fisik tidak dapat dipisahkan. Kedua hal tersebut merupakan satu rangkaian pertumbuhan dan perkembangan yang harus seimbang dalam proses pembinaan olahraga. Olahragawan merupakan satu totalitas sistem psikofisik yang kompleks. Artinya, manusia yang terdiri atas unsur jiwa dan raga, maka olahraga merupakan aktualisasi dari akumulasi perpaduan antara latihan, potensi fisik, dan psikologis. Faktor tersebut perlu dijalani dalam proses latihan secara seimbang terutama faktor psikologis dan fisik. Namun, kenyataan di lapangan para pelatih cenderung lebih banyak melatihkan unsur fisik daripada psikologis, sehingga proses latihan belum berjalan seimbang. Faktor psikologis perlu dilatihkan secara seimbang, karena erat kaitannya dengan pembinaan karakter olahragawan, yaitu emosi. Emosi diperlukan dalam proses olahraga, tetapi emosi yang di luar kendali akan mengganggu kinerja (performance) olahraga- wan untuk mencapai performance (penampilan) terbaik. Setiap olahragawan memiliki gejolak dan reaksi emosional yang berbeda-beda. Untuk itu para pelatih harus mengetahui cara untuk memantau reaksi emosional, agar dapat membantu olahragawan dan memberikan solusi terbaik dalam meraih prestasi (Sarwono, 2012, p. 130).

Olahragawan yang dalam kondisi emosi negatif, produksi kelenjar dirangsang dan hormon dikeluarkan untuk tetap menjaga keseimbangan tubuh. Hal itu yang mengakibatkan antara olahraga dan emosi merupakan sesuatu yang selalu berdampingan, artinya aktivitas olahraga akan berdampak pada munculnya emosi. Emosi dalam olahraga dapat mengubah perilaku seseorang, yang negatif dapat mengganggu koordinasi gerak yang halus dan kompleks, serta menghambat kinerja di lapangan. Perubahan perilaku seseorang akibat emosi negatif antara lain ditunjukkan dengan sikap kasar, liar, pemarah, dan kata-kata kotor, sehingga koordinasi gerak terganggu, gerakannya kaku, dan akurasinya berkurang.

Menurut Sarwono (2012, pp. 137-140), psikologis erat hubunganya dengan motif. Motif atau dalam bahasa Inggris "motive", berasal dari kata movere atau motion, yang berarti gerakan atau sesuatu yang bergerak. Gerak yaitu gerakan yang dilakukan manusia dalam bentuk perbuatan atau perilaku. Motif dalam psikologi berarti juga rangsangan, dorongan, atau pembangkit tenaga bagi terjadinya perbuatan (action) atau perilaku (behavior).

Motivasi merupakan istilah yang merujuk kepada seluruh proses gerakan, termasuk situasi yang mendorong, dorongan yang timbul dalam diri manusia, perilaku yang ditimbulkan oleh situasi tersebut dalam tujuan atau akhir akhir daripada tindakan atau perbuatan.

Motivasi sebagai salah satu objek psikologis dalam olahraga sepakbola. Kuat lemahnya motivasi dalam sepakbola menentukan kegairahan bermain sepakbola dan banyak sedikitnya pelaku olahraga, menentukan semangan, gembira, dan disiplin seseorang dalam melakukan latihan dan pertandingan.

Menurut Setyobroto (1989, p. 30), motivasi berkaitan erat dengan tingkat aspirasi individu yang bersangkutan. Apabila tingkat aspirasi seseorang lebih tinggi dari kemampuannya, dan anak tersebut selalu gagal untuk mencapainya, akan dapat memberi pengaruh buruk pada motivasi. Untuk itu agar motivasi anak terus terjaga dengan baik selama melak- 
sanakan program olahraga sepakbola, pelatih harus mengetahui perkembangan dan situasi fisik dan psikologis anak untuk menentukan jenis, intensitas latihan sepakbola yang tepat dalam berlatih sepakbola.

Dalam olahraga sepakbola interaksi antar atlet, interaksi atlet dengan pelatih, dan antara anggota tim satu dengan tim lain, penonton, media masa, lingkungan masyarakat sekitar dapat menimbulkan psikologis (emosi) tertentu. Interaksi anak berupa kegiatan bermain antar anak sangat dibutuhkan dengan cara bermain kerja sama dalam kelompok.

Menurut Arends \& Kilcher (2010, p. 306), kerja sama adalah bentuk model latihan atau strategi yang dicirikan oleh tugas kelompok, tujuan, struktur penghargaan, dan membutuhkan seseorang untuk secara aktif, dan kerja sama tim terlibat dalam proses latihan. Latihan kerja sama adalah pembelajaran yang lebih dimediasi oleh kelompok latihan daripada oleh pelatih. Bekerja dalam kelompok bertujuan untuk mengajari diri seseorang sendiri mengenai isi materi tigas atau kegiatan yang diberikan. Dalam proses kerja sama suatu kelompok diharapkan untuk saling membantu, mendukung, dan saling mengisi kelemahan dalam masingmasing anak untuk berhasil bersama. Kerja sama antar anak akan mampu meminimalisir anak merasa terbebani dalam melaksanakan kegiatan yang diberikan, dan sekaligus membangun kebersamaan. Hal ini sesuai dengan tipe olahraga sepakbola yang membutuhkan kerja sama didalamnya agar dapat terlaksana dengan baik.

Selain kegiatan secara berkelompok, untuk dapat meningkatkan aspek psikologis anak dalam berlatih sepakbola, kegiatan perlu menerapkan konsep bermain. Hal ini dikarena usia anak merupakan masa dimana sebagian besar waktunya dihabiskan dengan bermain (Musfiroh, 2008, p. 1).

Menurut Tedjasaputra (2005, p. 39), bermain mempunyai manfaat untuk membantu proses perkembangan aspek fisik, aspek motorik kasar dan motorik halus, perkembangan aspek sosial, dan perkembangan aspek psikologis. Perkembangan aspek kognisi mengasah ketajaman penginderaan, mengembangkan keterampilan olahraga, media terapi, serta media intervensi.

Untuk mencapai manfaat positif dari bermain dibutuhkan alat permainan yang tepat untuk peserta didik. Oleh karena itu, dalam pemilihan alat permainan sebaiknya memper- hatikan hal-hal sebagai berikut: (1) Alat permainan tidak berbahaya bagi peserta didik. (2) Bukan pilihan orang tua tetapi berdasarkan minat peserta didik terhadap mainan tersebut. (3) Alat permainan sebaiknya beraneka macam, sehingga peserta didik berekplorasi dengan berbagai macam alat permainannya. (4) Tingkat kesulitan sebaiknya disesuaikan pada rentang usia peserta didik. Permainan tidak terlalu sulit dan juga tidak terlalu mudah bagi peserta didik. (5) Peralatan permainan tidak terlalu rapuh.

Dalam bermain sepakbola faktor psikologis juga sangat penting. Menurut Scheunemann (2012, p. 164), faktor psikologis sangatlah penting dalam perkembangan seorang pemain sepakbola. Tanpa psikologis yang baik seorang pemain tidak akan bisa memperlihatkan semua kemampuannya di atas lapangan hijau. Begitu juga dengan permainan sebagai tim (atau teamwork) tidak akan bisa terjalin dengan baik apabila hubungan antar pemain tidak harmonis. desain latihan yang diberikan berbeda dengan yang diberikan bagi orang dewasa, hal ini disebabkan karena anak-anak masih dalam masa pertumbuhan dan perkembangan, dikhawatirkan jika bentuk latihan yang diuberikan pada anak sama dengan yang diberikan pada orang dewasa maka hal ini akan mengganggu proses pertumbuhan dan perkembangan anak.

Lebih lanjut dijelaskan agar psikologis (mental) dan fisik anak usia 12-13 tahun dapat berkembang dalam olahraga sepakbola, bagian terpenting latihan adalah yang bersifat teknis. Para pemain pada usia ini telah memiliki peningkatan yang baik tentang pengertian permainan. Sangat baik dalam usia ini mengembangkan teknik dan pengertian akan taktik dasar. Pada tingkat ini, pemain ada pada masa pra puber dan memiliki masalah keterbatasan fisik terutama pada kekuatan dan ketahanannya. Latihan yang diberikan hanya sebatas kelincahan (agility), kecepatan, koordinasi, dan keseimbangan yang dilakukan menggunakan bola. Bentuk kegiatan yang diberikan juga harus bervariasi dilaksanakan secara kelompok.

Menurut Sukadiyanto \& Muluk (2011, p. 20 ), sesuai prinsip variasi latihan program latihan seperti pada latihan sirkuit yang baik harus disusun secara variatif untuk menghilangkan munculnya aspek psikologis negatif. Variasi latihan menekankan pada pemeliharaan keadaan psikologis olahragawan agar tetap bersemangat, gembira, dan disiplin dalam berlatih. Dalam menentukan jumlah variasi kegiatan latihan untuk yang singkat atau tahap pemula berjum- 
lah 6 macam, normal 9 macam, dan lama atau kalangan profesional berjumlah 12 macam.

Dari uraian di atas, rumusan masalahnya adalah: (1) Bentuk bermain sepakbola yang dikembangkan siswa sekolah sepakbola anak usia 12-13 tahun, (2) Bagaimana pelaksanaan latihan sepakbola menggunakan model bermain sepakbola yang dikembangkan, dan (3) Bagaimana tingkat efektivitas dari model bermain sepakbola anak usia 12-13 tahun yang digunakan siswa sekolah sepakbola di Yogyakarta.

\section{METODE}

\section{Jenis Penelitian}

Penelitian ini merupakan penelitian dan pengembangan (research and development), karena sesuai dengan tujuan yang hendak dicapai, yaitu mengembangkan modul bermain sepakbola anak untuk meningkatkan aspek psikologis berupa semangat, gembira, dan disiplin anak usia 12-13 tahun di Yogyakarta. Dalam penelitian dan pengembangan produk yang dihasilkan atau divalidasi berupa buku teks mengenai proses dan prosedur pelaksanaan model pembelajaran atau metode mengorganisir pembelajaran. Hal ini sejalan dengan pendapat Borg \& Gall (1983, p. 772) bahwa penelitian pengembangan adalah proses yang digunakan untuk mengembangkan dan memvalidasi produk-produk pendidikan, baik produk yang berupa objek material seperti buku teks, film pengajaran, dan sebagainya maupun produk yang berupa proses dan prosedur yang ditemukan seperti metode mengajar atau metode mengorganisir pengajaran.

\section{Tempat dan Waktu Penelitian}

Uji coba skala kecil dilakukan pada bulan Mei 2014 di SSB Real Madrid. Uji coba skala besar dilakukan pada bulan Juni 2014 di SSB real Madrid dan SSB Bina Putra Jaya Sleman.

\section{Subjek Penelitian}

Dalam penelitian ini teknik sampling yang digunakan adalah purposive sampling. Pada tahap validasi ahli subjek coba terdiri atas tiga ahli yaitu: ahli Psikologis, ahli latihan olahraga, dan pelatih sepakbola (praktisi). Pada tahap uji coba skala kecil penelitian dilakukan di SSB Real Madrid Yogyakarta terdiri atas 10 siswa dan satu pelatih sepakbola. Pada tahap uji coba skala besar melibatkan 2 tempat di SSB Real Madrid Yogyakarta dan SSB Bina Putra Jaya Sleman terdiri atas 38 siswa dan dua orang pelatih.

\section{Prosedur}

Prosedur pengembangan penelitian ini mengadaptasi langkah penelitian pengembangan Borg \& Gall (1983, p. 775), sebagai berikut: research and information collect, planing, develop preeliminary form product, preeliminary field testing, main product revision, main field testing, operational product revision, operational field testing, final product revision, dissemination and implementation.

Berdasarkan 10 langkah penelitian dan pengembangan tersebut, dalam penelitian ini pada proses pelaksanaannya melakukan adaptasi yang mengacu pada model pendekatan tersebut. Adapun adaptasi penelitian dan pengembangan ini menjadi 2 tahap yaitu: (1) tahap penelitian pendahuluan yang meliputi studi pustaka serta penelitian yang relevan dan studi lapangan dan (2) tahap pengembangan yang meliputi tahap perencanaan, tahap validasi ahli, dan tahap validasi empirik (uji skala kecil dan skala besar).

\section{Desain Uji Coba}

Uji coba dilakukan untuk untuk mengetahui tingkat kelayakan dan tingkat efektivitas dari model bermain sepakbola untuk meningkatkan aspek psikologis berupa semangat, gembira, dan disiplin anak usia 12-13 tahun di Yogyakarta.

Uji coba produk ini dilakukan dalam uji skala kecil dan uji skala besar. Model bermain sepakbola yang dikembangkan dikatakan layak apabila bisa digunakan dalam latihan sepakbola di sekolah sepakbola anak usia 12-13 tahun. Model ini juga dikatakan efektif apabila dapat meningkatkan perkembangan psikologis berupa semangat, gembira, dan disiplin anak siswa.

Uji coba model dilakukan dengan mengimplementasikan model bermain sepakbola yang dikembangkan dalam latihan sepakbola. Pelatih akan diberikan buku panduan dan diberikan penjelasan mengenai model bermain sepakbola yang dikembangkan untuk dilaksanakan dalam latihan. Pada saat dilakukan proses implementasi model akan dilakukan observasi untuk mengetahui kelayakan model. Setelah dilakukan observasi selanjutnya dilakukan evaluasi dan revisi model.

\section{Jenis Data}

Data dalam penelitian ini terdiri atas data kuantitatif dan data kualitatif. Data-data tersebut diperoleh dengan menggunakan tek- 
nik observasi dan kuesioner. Data kuantitatif meliputi data tentang perkembangan psikologis berupa semangat, gembira, dan disiplin anak selama penerapan model bermain sepakbola yang diperoleh dengan menggunakan instrumen penilaian perkembangan psikologis. Data kualitatif meliputi data tentang masukanmasukan dari ahli dan pelatih.

\section{Instrumen Pengumpulan Data}

Pada tahap penelitian pendahuluan pengumpulan data dimaksudkan untuk memperoleh informasi mengenai pelaksanaan dan hambatan kegiatan siswa sekolah sepakbola anak usia 12-13 tahun dalam kegiatan berlatih sepakbola.

Pada tahap pengembangan, instrumen yang digunakan untuk memperoleh data berupa kuesioner penilaian model yang akan dikembangkan. Kuesioner dan DVD hasil rekaman pelaksanaan diberikan kepada ahli untuk dievaluasi. Validasi dilakukan dengan memberikan masukan serta saran, dan penilaian. Penilaian untuk para ahli (validator) dengan menggunakan skala likert 1-5. Nilai 1 untuk sangat kurang, nilai 2 untuk kurang, nilai 3 untuk cukup, nilai 4 untuk baik, nilai 5 untuk sangat baik. Setelah penilaian dilakukan, hasil data penilaian validasi ahli terhadap model bermain sepakbola anak usia 12-13 tahun, kemudian data dikategorikan berdasarkan skala guttman yaitu skor 1-2 tergolong kurang, skor 3 tergolong cukup, dan skor 4-5 tergolong baik. Untuk data saran dan perbaikan didapat setelah para ahli melihat rekaman pelaksanaan melalui DVD, ahli menulis saran dan perbaikan pada kolom saran dan perbaikan yang disediakan.

Lembar observasi pelaksanaan model digunakan untuk mengamati pelaksanaan latihan menggunakan draf model bermain sepakbola. Lembar observasi ditujukan untuk pelatih/ pelaksana. Lembar observasi pelatih digunakan untuk memperoleh data mengenai tingkat kelayakan dari draft model yang dikembangkan dalam kondisi sesungguhnya/ lapangan. Format penilaian menggunakan skala likert 1-5. Nilai 1 untuk sangat kurang, nilai 2 untuk kurang, nilai 3 untuk cukup, nilai 4 untuk baik, nilai 5 untuk sangat baik. dalam lembar penilaian pelaksanaan terdapat dua aspek penilaian yaitu aspek substansi isi dan aspek pelaksanaan kegiatan. Aspek substansi isi terdiri atas dua item pertanyaan dengan nilai maksimal 10. Sedangkan aspek pelaksanaan terdiri atas delapan item pertanyaan dengan nilai maksimal 40. Setelah dihitung presentasenya menunjukpada angka $100 \%$.

Rubrik penilaian digunakan untuk mengukur tingkat pencapaian hasil latihan dengan mengunakan model bermain sepakbola anak usia 12-13 tahun. Rubrik penilaian disusun berdasarkan setiap indikator dalam permainan yang yang terdapat dalam model bermain sepakbola anak usia 12-13 tahun. Penilaian yang terdapat pada rubrik penilaian mencakup aspek psikologis anak berupa semangat, gembira, dan disiplin.

\section{Teknik Analisis Data}

Data yang diperoleh pada penelitian pendahuluan akan dianalisis dengan menggunakan teknik analisis deskriptif kualitatif. Analisis deskriptif kualitatif digunakan pada angket studi pendahuluan. Teknik analisis deskriptif bertujuan untuk menjelaskan karakteristik masing-masing variabel dan mempresentasikan secara objektif terhadap data-data yang diperoleh.

Pada tahap pengembangan data yang diperoleh akan dianalisis menggunakan beberapa pendekatan yaitu: (1) Pada tahap validasi draf model, data yang diperoleh akan dideskripsikan ke dalam bentuk sajian data dan dianalisis secara kualitatif dan (2) Pada uji skala kecil dan besar hasil uji coba dianalisis menggunakan pendekatan analisis deskriptif dan analisis kuantitatif (statistik). Analisis kuantitatif (statistik) menggunakan analisis statistik uji beda dengan menggunakan statistik non parametrik dengan uji Wilcoxon Signed Ranks Test.

\section{HASIL DAN PEMBAHASAN}

Berdasarkan tujuan penelitian dan pengembangan, hasil penelitian ini terdiri atas lima aspek yaitu: (1) studi lapangan; (2) perencanaan dan penyusunan draf awal; (3) validasi ahli; dan (4) validasi empirik yang meliputi uji skala kecil dan besar.

\section{Studi Lapangan}

Studi pendahuluan bertujuan untuk mengetahui permasalahan yang terjadi di lapangan berkaitan dengan program pembinaan sepakbola anak usia 12-13 tahun. Peneliti melakukan observasi dan wawancara pada pelatih berkaitan dengan program pembinaan sepakbola anak usia 12-13 tahun.

Berdasarkan hasil studi lapangan diketahui bahwa siswa sangat semangat dan senang berlatih dengan menggunakan bola dan dilaku- 
kan secaara berkelompok. Akan tetapi dalam pemberian program pembinaan sepakbola, pelatih selalu memberikan bentuk latihan yang fokus pada program pengembangan aspek fisik, sehingga anak kurang termotivasi untuk melakukan program pembinaan yang diberikan pelatih. pelatih masih kesulitan mengembangkan bentuk kegiatan yang mengkombinasikan aspek fisik, psikologis, dan bermain sepakbola. Pelatih merasa perlu model bermain sepakbola yang dapat melatih kemampuan fisik dan meningkatkan aspek psikis berupa semangat, gembira, dan disiplin.

\section{Perencanaan dan Penyusunan Draf Awal}

Berdasarkan studi lapangan, kajian pustaka dan penelitian yang relevan dihasilkan dua aspek bermain sepakbola yang dikembangkan yaitu desain model bermain dan implementasi model bermain. Dalam pengembangan desain model bermain aspek yang dikembangkan adalah konsep model, tujuan, pendekatan dan metode bermain, prosedur pelaksanaan dan penilaian hasil bermain. Dalam pengembangan implementasi bermain diarahkan pada pelaksanaan model bermain sepakbola.

Peneliti mengembangkan model bermain sepakbola yang dapat meningktakan aspek psikologis anak berupa semangat, gembira, dan disiplin dalam berlatih sepakbola. model ini diharapkan dapat melatih fisik anak dan perkembangan psikologis anak dalam bermain sepakbola. model latihan terdiri atas tiga tahapan latihan yaitu: Tahap pemanasan, pada tahap ini bentuk kegiatan berupa kegiatan aktif menggunakan bola dilakukan secara berkelompok selama 10 menit dilanjutkan dengan peregangan statis dan dinamis. Tahap inti, bentuk kegiatan terdiri atas delapan bentuk kegiatan bermain menggunakan bola dan dilakukan secara berkelompok. Bentuk kegiatan berisi tentang gerak dasar sepakbola berupa passing, stop, sundul, lompat dan loncat, dan lari. Kedelapan kegiatan yaitu: pasing berantai, kotak rintangan, kolong gawang, kotak berkembang, sundul bola, keliling bintang, jepit bola, pasing silang. Tahap pendinginan, pada tahap ini berisi kegiatan pasif menggunakan bola yang dilakukan dengan cara berkelompok selama lima menit dilanjutkan peregangan statis dan dinamis.

\section{Validasi Ahli}

Tabel 1. Data Validasi Ahli terhadap Model Bermain Sepakbola

\begin{tabular}{lllccc}
\hline \multirow{2}{*}{ No } & \multirow{2}{*}{ Aspek Penilaian } & \multicolumn{3}{c}{ Ahli/Paktisi } & \multirow{2}{*}{$\Sigma$} \\
\cline { 3 - 5 } & & $\mathbf{A 1}$ & $\mathbf{A 2}$ & $\mathbf{P}$ & \\
\hline 1 & Isi Materi & 4,75 & 4,5 & 4,25 & 4,5 \\
2 & Peralatan & 4,5 & 4,5 & 4,25 & 4,4 \\
3 & Metode & 4,4 & 4,4 & 4,2 & 4,3 \\
4 & Bahasa & 4 & 4,5 & 4 & 4,1 \\
\hline
\end{tabular}

Berdasarkan Tabel 1, aspek penilaian isi materi oleh ketiga ahli menunjukkan skor 4,5 artinya isi materi baik. Aspek penilaian peralatan dan fasilitas oleh ke tiga ahli menunjukkan skor 4,4 artinya peralatan dan fasilitas yang digunakan baik. Aspek penilaian motode bermain sepakbola oleh ketiga ahli menunjukkan 4,3 artinya metode yang digunakan baik. Aspek penilaian bahasa oleh ketiga ahli menunjukkan 4,1 artinya bahasa yang digunakan baik. Dapat disimpulkan bahwa berdasarkan validasi ahli terhadap model bermain sepakbola anak usia 12-13 tahun tergolong baik sehingga model yang dikembangkan layak diujicobakan.

\section{Uji Pelaksanaan Model}

Penilaian pelaksanaan model bermain sepakbola anak usia 12-13 tahun dilakukan pada uji coba skala kecil dan uji coba skala besar. Penilaian pelaksanaan model bermain pada uji coba skala kecil dilakukan di SSB Real Madrid yaitu sebagai berikut:

Tabel 2. Pelaksanaan Model Bermain Sepakbola pada Tahap Uji Coba Skala Kecil

\begin{tabular}{clcc}
\hline No & $\begin{array}{c}\text { Nama } \\
\text { Kegiatan }\end{array}$ & $\begin{array}{c}\text { Aspek } \\
\text { Penilaian }\end{array}$ & $\begin{array}{c}\text { Penilaian } \\
\text { Praktisi }\end{array}$ \\
\hline 1 & $\begin{array}{l}\text { Passing } \\
\text { Berantai }\end{array}$ & $\begin{array}{c}\text { Substansi isi } \\
\text { Pelaksanaan }\end{array}$ & $\begin{array}{c}\text { Sangat baik } \\
\text { Baik }\end{array}$ \\
\multirow{2}{*}{2} & Kotak & Substansi isi & Baik \\
& Rintangan & Pelaksanaan & Sangat baik \\
\multirow{2}{*}{3} & Kolong & Substansi isi & Baik \\
& Gawang & Pelaksanaan & Baik \\
4 & Kotak & Substansi isi & Sangat baik \\
& Berkembang & Pelaksanaan & Sangat baik \\
5 & Sundul Bola & Substansi isi & Sangat baik \\
& Keliling & Pelaksanaan & Sangat baik \\
6 & Bintang & Substansi isi & Sangat baik \\
& & Pelaksanaan & Sangat baik \\
\hline
\end{tabular}

Berdasarkan Tabel 2, hasil penilaian pelaksanaan model bermain sepakbola anak usia 12-13 tahun didapatkan data yaitu: (1) Pada kegiatan passing berantai nilai pada aspek substansi isi 9 (90\%) artinya sangat baik, dan aspek pelaksanaan $32(80 \%)$ artinya baik. (2) Pada kegiatan kotak rintangan nilai substansi isi 
$8(80 \%)$ artinya baik, dan aspek pelaksanaan 35 $(87,5 \%)$ artinya sangat baik. (3) Pada kegiatan kolong gawang nilai substansi isi $7(70 \%)$ artinya baik dan pelaksanaan $29(72,5 \%)$ artinya baik. (4) Pada kotak berkembang nilai substansi isi $7(70 \%)$ artinya baik, dan pelaksanaan 29 $(72,5 \%)$ artinya baik. (5) Pada sundul bola nilai substansi isi $9(90 \%)$ artinya sangat baik dan pelaksanaan $33(82,5 \%)$ artinya sangat baik. (6) Pada kegiatan keliling bintang nilai substansi isi 9 (90\%) sangat baik dan pelaksanaan 35 $(87,5 \%)$ artinya sangat baik. Dari hasil penilaian pelaksanakan model dapat disimpulkan bahwa hasil pelaksanaan kegiatan latihan menggunakan model bermain sepakbola anak usia 12-13 tahun pada uji coba skala kecil dapat dilaksanakan dan menunjukkan model bermain sepakbola dapat berpengaruh pada aspek psikologis (semangat, gembira, dan disiplin) anak usia 12-13 tahun, petunjuk pelaksanaan jelas, peralatannya yang digunakan sesuai, mudah, aman, menarik, dan bermanfaat bagi siswa dan pelatih.

Uji coba pelaksanaan model bermain sepakbola pada uji coba skala besar dilakukan di SSB Real Madrid dan SSB Bina Putra Jaya Sleman dilakukan oleh dua pelatih. Hasil penilaian pelaksanaan model pada uji coba skala besar dapat dilihat pada Tabel 3 .

Hasil penilaian pelaksanaan model bermain sepakbola anak usia 12-13 tahun didapatkan data yaitu: (1) kegiatan passing berantai berdasarkan pelatih ke-1 nilai substansi isi 9 (90\%) artinya sangat baik dan pelaksanaan 36 $(90 \%)$ artinya sangat baik, berdasarkan pelatih ke-2 nilai substansi isi $10(100 \%)$ dan pelaksanaan $37(92,5 \%)$ artinya sangat baik.(2) kegiat- an kotak rintangan berdasarkan pelatih ke-1 nilai substansi isi 9 (90\%) artinya sangat baik dan pelaksanaan $37(92,5 \%)$ artinya sangat baik, berdasarkan pelatih ke-2 nilai substansi isi $10(100 \%)$ dan pelaksanaan $39(97,5 \%)$ artinya sangat baik. (3) kegiatan kolong gawang berdasarkan pelatih ke-1 nilai substansi isi $8(80 \%)$ artinya sangat baik dan pelaksanaan $33(82,5 \%)$ artinya sangat baik, berdasarkan pelatih ke-2 nilai substansi isi 9 (90\%) dan pelaksanaan 39 $(97,5 \%)$ artinya sangat baik. (4) kegiatan kotak berkembang berdasarkan pelatih ke-1 nilai substansi isi 9 (90\%) artinya sangat baik dan pelaksanaan $35(87,5 \%)$ artinya sangat baik, berdasarkan pela-tih ke-2 nilai substansi isi 9 (90\%) dan pelaksanaan $37(92,5 \%)$ artinya sangat baik. (5) kegiatan sundul bola berdasarkan pelatih ke-1 nilai substansi isi 9 (90\%) artinya sangat baik dan pelaksanaan 34 (85\%) artinya sangat baik, berdasarkan pelatih ke-2 nilai substansi isi $10(100 \%)$ dan pelaksanaan $35(87,5 \%)$ artinya sangat baik. (6) kegiatan keliling bintang berdasarkan pelatih ke-1 nilai substansi isi $9(90 \%)$ artinya sangat baik dan pelaksanaan $36(90 \%)$ artinya sangat baik, berdasarkan pelatih ke-2 nilai substansi isi 9 (90\%) dan pelaksanaan 37 (92\%) artinya sangat baik. Dari hasil penilaian pelaksanaan, dapat disimpulkan bahwa hasil pelaksanaan kegiatan latihan menggunakan model bermain sepakbola anak usia 12-13 tahun pada uji coba skala besar menunjukkan model bermain dapat berpengaruh pada aspek psikologis anak, petunjuk pelaksanaan jelas, peralatannya yang digunakan sesuai, mudah, aman, menarik, dan bermanfaat bagi siswa dan pelatih.

Tabel 3. Pelaksanaan Model Bermain Sepakbola pada Uji Coba Skala Besar

\begin{tabular}{|c|c|c|c|c|}
\hline No & Nama Kegiatan & Aspek Penilaian & Penilaian (P1) & Penilaian (P2) \\
\hline \multirow{2}{*}{1} & \multirow{2}{*}{ Passing Berantai } & Substansi Isi & Sangat Baik & Sangat Baik \\
\hline & & Pelaksanaan & Sangat Baik & Sangat Baik \\
\hline \multirow{2}{*}{2} & \multirow{2}{*}{ Kotak Rintangan } & Substansi Isi & Sangat Baik & Sangat Baik \\
\hline & & Pelaksanaan & Sangat Baik & Sangat Baik \\
\hline \multirow{2}{*}{3} & \multirow{2}{*}{ Kolong Gawang } & Substansi Isi & Sangat Baik & Sangat Baik \\
\hline & & Pelaksanaan & Sangat Baik & Sangat Baik \\
\hline \multirow{2}{*}{4} & \multirow{2}{*}{ Kotak Berkembang } & Substansi Isi & Sangat Baik & Sangat Baik \\
\hline & & Pelaksanaan & Sangat Baik & Sangat Baik \\
\hline \multirow{2}{*}{5} & \multirow{2}{*}{ Sundul Bola } & Substansi Isi & Sangat Baik & Sangat Baik \\
\hline & & Pelaksanaan & Sangat Baik & Sangat Baik \\
\hline \multirow{2}{*}{6} & \multirow{2}{*}{ Keliling Bintang } & Substansi Isi & Sangat Baik & Sangat Baik \\
\hline & & Pelaksanaan & Sangat Baik & Sangat Baik \\
\hline
\end{tabular}


Jurnal Keolahragaan 4 (1), April 2016 - 42

Muna Aprilianto, Tomoliyus

Tabel 4. Data Hasil Uji Efektivitas Model Bermain Sepakbola Usia 12-13 Tahun pada Uji Coba Skala Kecil

\begin{tabular}{|c|c|c|c|c|}
\hline Kegiatan & Uji Coba Ke-1 dan Ke-2 & Semangat & Gembira & Disiplin \\
\hline \multirow{4}{*}{ Pasing Berantai } & Mean Uji Coba 1 & 2,3 & 2,4 & 2,3 \\
\hline & Mean Uji Coba 2 & 3,6 & 3,5 & 3,6 \\
\hline & $\mathrm{t}$ & $-4,9993$ & $-6,128$ & $-6,091$ \\
\hline & Asymp. Sig. (2-tailed) &, 001 &, 000 &, 000 \\
\hline \multirow{4}{*}{ Kotak Rintangan } & Mean Uji Coba 1 & 2,3 & 2,3 & 2,4 \\
\hline & Mean Uji Coba 2 & 3,6 & 3,5 & 3,6 \\
\hline & $\mathrm{t}$ & $-4,993$ & $-4,811$ & $-4,129$ \\
\hline & Asymp. Sig. (2-tailed) &, 001 & 001 &, 003 \\
\hline \multirow{4}{*}{ Kolong Gawang } & Mean Uji Coba 1 & 2,3 & 2,3 & 2,3 \\
\hline & Mean Uji Coba 2 & 3,4 & 3,5 & 3,4 \\
\hline & $\mathrm{t}$ & $-3,973$ & $-4,129$ & $-6,128$ \\
\hline & Asymp. Sig. (2-tailed) &, 003 &, 003 &, 000 \\
\hline \multirow{4}{*}{ Kotak Berkembang } & Mean Uji Coba 1 & 2,4 & 2,4 & 2,4 \\
\hline & Mean Uji Coba 2 & 3,5 & 3,6 & 3,5 \\
\hline & $\mathrm{t}$ & $-3,973$ & $-9,000$ & $-4,714$ \\
\hline & Asymp. Sig. (2-tailed) &, 003 &, 000 &, 001 \\
\hline \multirow{4}{*}{ Sundul Bola } & Mean Uji Coba 1 & 2,4 & 2,4 & 2,4 \\
\hline & Mean Uji Coba 2 & 3,5 & 3,5 & 3,5 \\
\hline & $\mathrm{t}$ & $-4,714$ & $-3,973$ & $-6,128$ \\
\hline & Asymp. Sig. (2-tailed) & ,001 & ,003 &, 000 \\
\hline \multirow{4}{*}{ Keliling Bintang } & Mean Uji Coba 1 & 2,3 & 2,4 & 2,4 \\
\hline & Mean Uji Coba 2 & 3,5 & 3,5 & 3,5 \\
\hline & $\mathrm{t}$ & $-4,811$ & $-4,714$ & $-4,714$ \\
\hline & Asymp. Sig. (2-tailed) &, 001 & ,001 &, 001 \\
\hline
\end{tabular}

\section{Uji Efektivitas Perkembangan Psikologis}

Uji efektivitas terhadap perkembangan psikologis anak dalam menggunakan model bermain sepakbola terdiri atas dua tahap yaitu: tahap uji coba skala kecil dilakukan selama dua kali pertemuan. Hasil uji coba efektivitas perkembangan psikologis terdapat pada Tabel 4. Pada tahap uji coba skala besar dilakukan di dua tempat yaitu SSB Real Madrid dan SSB Bina Putra Jaya Sleman, uji coba masingmasing dilakukan selama dua kali pertemuan. Hasil uji oba efektivitas perkembangan psikologis terdapat pada Tabel 5.

\section{Uji Coba Skala Kecil}

Uji coba skala kecil dilakukan di SSB Real Madrid. Hasil penilaian efektivitas perkembangan psikologis berupa semangat, gembira dan disiplin siswa usia 12-13 tahun pada uji skala kecil terdapat pada Tabel 4.

Berdasarkan hasil perhitungan pada tabel 4, nilai signifikansi pada passing berantai, kotak rintangan, kolong gawang, kotak berkembang, sundul bola, dan keliling bintang lebih rendah dari 0,05 atau $\rho<0,05$. Berdasarkan kriteria pengambilan keputusan yang sudah ditetapkan maka $\mathrm{H}_{0}$ ditolak. Hal ini menunjukkan bahwa terdapat perbedaan yang signifikan pada pada passing berantai, kotak rintangan, kolong gawang, kotak berkembang, sundul bola, dan keliling bintang pada pertemuan pertama dengan pertemuan kedua.

Berdasarkan hasil data penilaian perkembangan psikologis anak di uji coba skala kecil di atas, dapat disimpulkan model bermain bisa diterapkan dalam proses latihan, dan dapat meningkatkan aspek psikologis anak berupa semangat, gembira, dan disiplin dalam melakukan latihan menggunakan model bermain sepakbola anak usia 12-13 tahun. Hasil penilaian perkembangan psikologis berupa aspek semangat, gembira, dan disiplin anak oleh pelatih melalui penilaian dengan pengamatan secara langsung dilapangan pada saat uji coba skala kecil dapat dianalisis bahwa dalam program latihan dibutuhkan aspek psikologis sebagai rangsangan anak untuk dapat melaksanakan kegiatan bermain sepakbola. Model bermain sepakbola ini dapat memotivasi anak dalam berpartisipasi aktif dalam proses latihan sepakbola, hal ini karena bentuk model bermain memiliki variasi kegiatan, kegiatan bermain, dilakukan secara berkelompok. 


\section{Uji Skala Besar}

Pada uji coba skala besar dilakukan di dua tempat yang berbeda. Uji coba dilakukan di SSB Real Madrid dan SSB Bina Putra Jaya Sleman. Hasil penelitian pada uji coba skala besar yaitu sebagai berikut:

\section{SSB Real Madrid}

Hasil Uji coba skala besar di SSB Real Madrid Terdapat pada Tabel 5. Berdasarkan hasil perhitungan pada Tabel 5, nilai signifikansi pada passing berantai, kotak rintangan, kolong gawang, kotak berkembang, sundul bola, dan keliling bintang lebih rendah dari 0,05 atau $\rho<0,05$. Berdasarkan kriteria pengambilan keputusan yang sudah ditetapkan maka $\mathrm{H}_{0}$ ditolak. Hal ini menunjukkan bahwa terdapat perbedaan yang signifikan pada pada passing berantai, kotak rintangan, kolong gawang, kotak berkembang, sundul bola, dan keliling bin- tang pada pertemuan pertama dengan pertemuan kedua.

Berdasarkan hasil data penilaian perkembangan psikologis anak di SSB Real Madrid dalam uji coba skala besar tersebut, dapat disimpulkan model bermain bisa diterapkan dalam proses latihan, dan dapat meningkatkan aspek psikologis anak berupa semangat, gembira, dan disiplin. Hasil penilaian perkembangan psikologis berupa aspek semangat, gembira, dan disiplin anak oleh pelatih melalui observasi dengan pengamatan secara langsung di lapangan pada saat uji coba skala besar dapat dianalisis bahwa dalam program latihan dibutuhkan aspek psikologis sebagai rangsangan anak untuk dapat melaksanakan kegiatan latihan. Model bermain ini dapat memotivasi anak dalam berpartisipasi aktif dalam proses latihan sepakbola, hal ini karena bentuk model bermain memiliki variasi kegiatan, kegiatan bermain, dilakukan secara berkelompok.

Tabel 5. Data Hasil Uji Efektivitas Model Bermain Sepakbola Usia 12-13 Tahun di SSB Real Madrid pada Uji Coba Skala Besar

\begin{tabular}{clccc}
\hline Kegiatan & \multicolumn{1}{c}{ Uji Coba Ke-1 dan Ke-2 } & Semangat & Gembira & Disiplin \\
\hline \multirow{5}{*}{ Pasing Berantai } & Mean Uji Coba 1 & 2,72 & 2,68 & 2,72 \\
& Mean Uji Coba 2 & 3,27 & 3,31 & 3,27 \\
& $\mathrm{t}$ & $-3,464$ & $-5,137$ & $-3,464$ \\
& Asymp. Sig. (2-tailed) &, 002 &, 000 &, 002 \\
& Mean Uji Coba 1 & 2,72 & 2,72 & 2,72 \\
& Mean Uji Coba 2 & 3,27 & 3,22 & 3,31 \\
& $\mathrm{t}$ & $-3,464$ & $-3,487$ & $-3,052$ \\
& Asymp. Sig. (2-tailed) &, 002 &, 002 &, 006 \\
& Mean Uji Coba 1 & 2,68 & 2,68 & 2,63 \\
Kolong Gawang & 3,18 & 3,22 & 3,18 \\
& Mean Uji Coba 2 & $-3,169$ & $-3,464$ & $-3,464$ \\
& $\mathrm{t}$ &, 005 &, 002 &, 002 \\
& Asymp. Sig. (2-tailed) & 2,68 & 2,72 & 2,68 \\
& Mean Uji Coba 1 & 3,27 & 3,27 & 3,31 \\
& Mean Uji Coba 2 & $-3,480$ & $-3,196$ & $-4,537$ \\
& $\mathrm{t}$ &, 002 &, 004 &, 000 \\
& Asymp. Sig. (2-tailed) & 2,72 & 2,72 & 2,77 \\
& Mean Uji Coba 1 & 3,27 & 3,31 & 3,31 \\
& Mean Uji Coba 2 & $-3,464$ & $-4,161$ & $-3,196$ \\
& $\mathrm{t}$ &, 002 &, 000 &, 004 \\
& Asymp. Sig. (2-tailed) & 2,72 & 2,68 & 2,72 \\
& Mean Uji Coba 1 & 3,31 & 3,27 & 3,31 \\
& Mean Uji Coba 2 & $-3,480$ & $-4,161$ & $-3,480$ \\
& &, 002 &, 000 &, 002 \\
\hline
\end{tabular}


Jurnal Keolahragaan 4 (1), April 2016 - 44

Muna Aprilianto, Tomoliyus

SSB Bina Putra Jaya Sleman

Tabel 6. Data Hasil Uji Efektivitas Model Bermain Sepakbola Usia 12-13 Tahun di SSB Bina Putra Jaya Sleman Pada Uji Coba Skala Besar

\begin{tabular}{|c|c|c|c|c|}
\hline Kegiatan & Uji Coba ke-1 dan ke-2 & Semangat & Gembira & Disiplin \\
\hline \multirow{4}{*}{ Pasing Berantai } & Mean Uji Coba 1 & 2,62 & 2,68 & 2,62 \\
\hline & Mean Uji Coba 2 & 3,43 & 3,37 & 3,43 \\
\hline & $\mathrm{t}$ & $-5,975$ & $-3,467$ & $-4,333$ \\
\hline & Asymp. Sig. (2-tailed) & ,000 & ,003 & ,001 \\
\hline \multirow{4}{*}{ Kotak Rintangan } & Mean Uji Coba 1 & 2,68 & 2,68 & 2,68 \\
\hline & Mean Uji Coba 2 & 3,43 & 3,43 & 3,50 \\
\hline & $\mathrm{t}$ & $-4,392$ & $-3,873$ & $-5,975$ \\
\hline & Asymp. Sig. (2-tailed) & ,001 & ,002 &, 000 \\
\hline \multirow{4}{*}{ Kolong Gawang } & Mean Uji Coba 1 & 2,50 & 2,50 & 2,50 \\
\hline & Mean Uji Coba 2 & 3,31 & 3,31 & 3,31 \\
\hline & $\mathrm{t}$ & $-4,333$ & $-4,333$ & $-5,975$ \\
\hline & Asymp. Sig. (2-tailed) & ,001 & ,001 & , 000 \\
\hline \multirow{4}{*}{ Kotak Berkembang } & Mean Uji Coba 1 & 2,62 & 2,68 & 2,68 \\
\hline & Mean Uji Coba 2 & 3,43 & 3,43 & 3,43 \\
\hline & $\mathrm{t}$ & $-4,333$ & $-4,392$ & $-4,392$ \\
\hline & Asymp. Sig. (2-tailed) & ,001 &, 001 &, 001 \\
\hline \multirow{4}{*}{ Sundul Bola } & Mean Uji Coba 1 & 2,68 & 2,68 & 2,62 \\
\hline & Mean Uji Coba 2 & 3,37 & 3,43 & 3,43 \\
\hline & $\mathrm{t}$ & $-4,568$ & $-5,196$ & $-4,961$ \\
\hline & Asymp. Sig. (2-tailed) &, 000 &, 000 &, 000 \\
\hline \multirow{4}{*}{ Keliling Bintang } & Mean Uji Coba 1 & 2,68 & 2,62 & 2,68 \\
\hline & Mean Uji Coba 2 & 3,43 & 3,37 & 3,50 \\
\hline & $\mathrm{t}$ & $-3,873$ & $-5,196$ & $-4,333$ \\
\hline & Asymp. Sig. (2-tailed) & ,002 & ,000 & ,001 \\
\hline
\end{tabular}

Dari hasil perhitungan pada Tabel 6, nilai signifikansi pada passing berantai, kotak rintangan, kolong gawang, kotak berkembang, sundul bola, dan keliling bintang lebih rendah dari 0,05 atau $\rho<0,05$. Berdasarkan kriteria pengambilan keputusan yang sudah ditetapkan maka $\mathrm{H}_{0}$ ditolak. Hal ini menunjukkan bahwa terdapat perbedaan yang signifikan pada pada passing berantai, kotak rintangan, kolong gawang, kotak berkembang, sundul bola, dan keliling bintang pada pertemuan pertama dengan pertemuan kedua.

Berdasarkan hasil data penilaian perkembangan psikologis anak di SSB Real Madrid dalam uji coba skala besar tersebut, dapat disimpulkan model bermain bisa dite-rapkan dalam proses latihan, dan dapat meningkatkan aspek psikologis anak berupa semangat, gembira, dan disiplin. Hasil penilaian perkembangan psikologis berupa aspek semangat, gembira, dan disiplin anak oleh pelatih melalui observasi dengan pengamatan secara langsung dilapangan pada saat uji coba skala besar dapat dianalisis bahwa dalam program latihan dibutuhkan aspek psikologis sebagai rangsangan anak untuk dapat melak-sanakan kegiatan latihan. Model bermain ini dapat memotivasi anak dalam berpar-tisipasi aktif dalam proses latihan sepak-bola, hal ini karena bentuk model bermain memiliki variasi kegiatan, kegiatan bermain, dilakukan secara berkelompok.

Hasil perubahan signifikan pada penilaian perkembangan aspek psikologis anak berupa semangat, gembira, dan disiplin anak saat berlatih sepakbola menggunakan model bermain sepakbola anak usia 12-13 tahun karena model ini telah disesuaikan dengan karakteristik perkembangan dan pertumbuhan anak usia 12-13 tahun baik secara fisik maupun psikologis. Selain daripada itu pelaksanaan kegiatan dilakukan lebih dari satu kali. Hal ini sesuai dengan teori kegiatan latihan/aktivitas yang dikemukakan oleh Thondrike dan diperkuat oleh Maimunah Hasan. Berikut penjelasan kedua tokoh. 
Peningkatan kemampuan yang terjadi dikarenakan adanya asosiasi pengetahuan yang diperoleh siswa pada pertemuan sebelumnya dengan pengetahuan yang baru dan asosiasi tersebut semakin kuat ketika dilakukan secara berulang. Hal ini berdasarkan pada teori belajar law of exercise yang dikemukakan oleh Thondrike (Rahyubi, 2012, p. 164) yang menyatakan bahwa "prinsip hukum latihan menunjukkan bahwa prinsip utama dalam belajar adalah pengulangan, semakin sering diulangi materi pelajaran akan semakin dikuasai”.

Hasan (2011, p. 32) yang menyatakan "pada tahap anak, koneksi yang diulang-ulang (mengalami pengulangan-pengulangan) akan menjadi permanen". Kaitannya dengan hasil penelitian yaitu bahwa model bermain sepakbola sekolah sepakbola anak usia dini kelompo atas dilakukan secara berulang-ulang akan menimbulkan koneksi saraf otak dan akan menjadi permanen sehingga makin meningkatkan kemampuan dalam hal kemampuan penunjang bermain sepakbola.

\section{SIMPULAN DAN SARAN}

\section{Simpulan}

Bentuk bermain sepakbola yang dikembangkan dalam model bermain sepakbola anak usia 12-13 tahun di sekolah sepakbola di Yogyakarta yaitu kegiatan bermain menggunakan bola, kegiatan bervariatif terdiri atas enam bentuk kegiatan bermain yang berbeda-beda, seluruh bentuk kegiatan bermain dilakukan secara berke-lompok. Hasil rancangan model bermain sepakbola anak usia 12-13 tahun terdiri atas tiga tahap latihan yaitu: tahap pendahuluan berupa penyampaian materi oleh pelatih dan melakukan pemanasan dengan kegiatan aktif menggunakan bola selama 10 menit, dan melakukan peregangan statis dan dinamis selama 5 menit, inti bermain melaksanakan kegiatan bermain berupa passing berantai, kotak rintangan, kolong gawang, kotak berkembang, sundul bola, dan keliling bintang selama 30-45 menit, dan penutup berupa kegiatan passif menggunakan bola selama lima menit dilanjutkan peregangan selama lima menit dan diakhiri dengan evaluasi bermain dan do'a penutup.

Pelaksanaan bermain menggunakan model bermain sepakbola anak usia 12-13 tahun di Yogyakarta berdasarkan hasil validasi oleh tiga ahli terhadap model bermain sepakbola anak usia 12-13 tahun di Yogyakarta dinyatakan layak untuk diujicobakan. Berdasarkan pada hasil implementasi model bermain sepakbola oleh pelatih sepakbola yang dilakukan melalui dua tahap yaitu tahap uji coba skala kecil dan tahap uji coba skala besar. Hasil implementasi model bermain sepakbola anak usia 12-13 tahun pada tahap uji coba skala kecil secara substansi isi sangat baik, pelaksanaan model sangat baik. Pada tahap uji coba skala besar secara substansi isi sangat baik, pelaksanaan model sangat baik. Berdasarkan uji coba model bermain sepakbola anak usia 12-13 tahun pada uji skala kecil dan besar maka dapat disimpulkan model latihan model yang dikembangkan.

Berdasarkan perhitungan efektivitas model yang dikembangkan diperoleh hasil bermain pertemuan kedua lebih tinggi dari hasil bermain pada pertemuan pertama. Artinya perkembangan psikologis berupa semangat, gembira, dan disiplin anak dalam bermain sepakbola menggunakan model bermain sepakbola anak usia 12-13 tahun mengalami peningkatan dari pertemuan pertama dan pertemuan kedua. Sehingga model bermain sepakbola anak usia 12-13 tahun efektif untuk meningkatkan aspek psikologis berupa semangat, gembira dan disiplin siswa sekolah sepakbola di Yogyakarta.

\section{Saran}

Berdasarakan kesimpulan hasil penelitian dan pengembangan, dan atas keunggulan yang dimiliki model bermain sepakbola anak usia 1213 tahun di Yogyakarta. Model bermain sepakbola anak usia 12-13 tahun di Yogyakarta dapat dipakai sebagai alternatif bagi pelatih dalam melaksanakan program pembinaan sepakbola anak usia 12-13 tahun di sekolah sepakbola di Yogyakarta. Model bermain sepakbola anak usia 12-13 tahun ini pelaksanaannya mudah, aman, serta menarik untuk dijadikan solusi yang lebih baik oleh pelatih dalam melatih anak bermain sepakbola. (2) Model bermain sepakbola anak usia 12-13 tahun telah teruji dapat meningkatkan aspek psikologis anak usia 12-13 tahun berupa semangat, kegembiraan, dan kedisiplinan. Pelatih harus bersungguh-sungguh dalam melaksanakan pembinaan sepakbola sesuai dengan prosedur yang telah dibuat sehingga dapat melakukan asesmen proses dan hasil belajar mengacu penilaian yang telah dibuat.

\section{DAFTAR PUSTAKA}

Arends, Richard I. (2010). Learning to teach: Belajar untuk mengajar. Alih Bahasa 


\section{Jurnal Keolahragaan 4 (1), April 2016 - 46}

Muna Aprilianto, Tomoliyus

Helly Prajitno Soetjipto, dkk. Yogyakarta: Pustaka Belajar.

Borg, W.R., \& Gall, M.D. (1983). Education research, $\left(7^{\text {th }}\right.$ ed. $)$. New York: Longman Inc.

Hasan, M. (2011). Pendidikan anak usia dini. Yogyakarta: Diva Press.

Lumintuarso, R. (2013). Pembinaan multilateral bagi atlet pemula. UNY Press.

Muhadjir, N. (2011). Metodelogi Penelitian Kualitatif. Yogyakarta: Bayu Indra Grafika.

Musfiroh, T. (2008). Cerdas melalui bermain. Jakarta. Grasindo.

Rahyubi, H. (2012). Teori-teori belajar dan aplikasi pembelajaran motorik. Bandung: Nusa Media.
Sarwono, S.W. (2012). Psikologi sosial: individu dan teori-teori psikologi sosial. Edisi 3. Jakarta: Balai Pustaka.

Scheunemann, S.T. (2012). Kurikulum dan pedoman dasar sepakbola indonesia. Jakarta: Badan Pembinaan Usia Muda PSSI.

Setyobroto, S. (1989). Psikologi olahraga. Jakarta: PT Anem KosongAnem.

Sukadiyanto. (2010). Pengantar teori dan metodelogi melatih fisik. Prodi PKO: FIK UNY.

Sukadiyanto \& Muluk, D. (2011). Pengantar teori dan metodologi melatih fisik. Bandung: CV. Lubuk Agung.

Tedjasaputra. (2005). Bermain, mainan, dan permainan. Jakarta: PT. Gramedia Widiasarana Indonesia. 